\title{
Contextualizing land-use and land-cover change with local knowledge: A case study from Pokot Central, Kenya
}

\author{
Maike Petersen ｜ Christoph Bergmann ｜ Paul Roden ｜ Marcus Nüsser
}

SAI, Department of Geography, Heidelberg University, Heidelberg, Germany

\section{Correspondence}

Marcus Nüsser, SAI, Department of Geography, Heidelberg University, Voßstraße 2, Building 4130, 69115 Heidelberg, Germany. Email: marcus.nuesser@uni-heidelberg.de

\section{Funding information}

Deutsche Forschungsgemeinschaft, Grant/ Award Number: NU 102/14-1; Heidelberg University, Graduiertenförderung

\begin{abstract}
Rural communities in the drylands of sub-Saharan Africa (SSA) derive their livelihoods primarily from their natural resource base. Unprecedented changes in these environments over the past few decades are likely to intensify in the future and land users need to develop sustainable adaptation strategies. This study aims to identify landuse and land-cover (LULC) changes and their drivers in a sub-Saharan dryland, between 1986 and 2017, by integrating local knowledge and remote sensing. Local knowledge and environmental perception are used as the basis for defining LULC classes and for training and validation of change detection. This study detects significant LULC changes in $41 \%$ of the investigated area, and identifies bush encroachment into former pastures as the dominant LULC change with an increase of woodland by $39 \%$ and a decrease of grassland by $74 \%$. This process is perceived as severe degradation by local respondents and is linked to changing management regimes and unreliable rainfall patterns. Deforestation and woodland thinning account for $44 \%$ of the detected changes, and can be traced back to increased habitation and farming, although the local community also identifies charcoal production as a driving factor. The integration of remote sensing and local knowledge provides a holistic view on LULC change in Pokot Central, Kenya and offers a solid base for sitespecific and actor-centred management approaches necessary for sustainable pathways of drylands. Our results emphasize the need to include local actors in the development of adaptation strategies and management guidelines for drylands.
\end{abstract}

\section{KEYWORDS}

Kenya, LANDSAT, land-use and land-cover change, local knowledge, Pokot Central, remote sensing

\section{1 | INTRODUCTION}

Rural communities in the drylands of sub-Saharan Africa (SSA) derive their livelihoods primarily from their natural resource base. Extensive changes in these environments over the past few decades are likely to intensify in the future and land users need to develop sustainable adaptation strategies. Palaeoenvironmental records over the past
2,000 years indicate that climate variations have always played an important role in shaping different livelihood pathways and migration patterns in Eastern Africa (Marchant et al., 2018; Verschuren, 2004). Current changes have been driven by local and external anthropogenic as well as ecological causes (Chalmers \& Fabricius, 2007; Liao, Agrawal, Clark, Levin, \& Rubenstein, 2020; Thondhlana, Vedeld, \& Shackleton, 2012). Future climate predictions for SSA indicate that 
the region will experience (if it has not already) less reliable precipitation patterns, more frequent and severe droughts, and more intense rainfall events (Funk et al., 2008; IPPC, 2014; Niang et al., 2014; Serdeczny et al., 2017; Shongwe, van Oldenborgh, van den Hurk, \& van Aalst, 2010). As a result of these drivers, current and predicted changes in plant biodiversity and ecosystem functioning present new challenges to rural communities. An improved understanding of how local land users perceive of, and manage their environment, is therefore required so that more appropriate land-use decisions can be made. One way to better understand human-environmental interactions and its effects on the environment is through the study of the patterns of land-use and land-cover (LULC) change.

The sub-Saharan region of Africa shows a heterogeneous pattern of LULC change, with agricultural land replacing natural vegetation as the most prominent transformation (Ordway, Asner, \& Lambin, 2017; Rukundo et al., 2018; Xu et al., 2018) and with another major trend showing an increase of woody vegetation at the expense of grasslands (Archer et al., 2017; Brandt et al., 2017; Marston, Aplin, Wilkinson, Field, \& O'Regan, 2017; Nüsser, 2002; Osborne et al., 2018). The rapid encroachment of woody species in the drylands has reduced the availability of grazing resources for pastoralists prompting them to adjust their land-based livelihood strategies (M. Becker et al., 2016), for example by diversifying their livestock mix to include more browsers (goats and camels) so as to exploit these woody species (Kagunyu \& Wanjohi, 2014; Ouko et al., 2020; Vehrs, 2016). Whilst some pastoralists increasingly include other non-land-based livelihood strategies such as wage labour or small business (Bergmann, Roden, \& Nüsser, 2019). Changes in LULC patterns do have knock-on effects on the well-being of land users that are not immediately obvious. For example, a reduction or complete loss of vegetation cover does not only cause more frequent flooding events and landslides but can also increase the risk of vector- and waterborne diseases (Anthonj, Diekkrüger, Borgemeister, \& Kistemann, 2019; Levy, Woster, Goldstein, \& Carlton, 2016; Okaka \& Odhiambo, 2018), and, a decrease in tree cover reduces the availability of fuel wood and increases the workload, particularly for women, during wood collection (Garedew, Sandewall, Söderberg, \& Campbell, 2009; Yiran, Kusimi, \& Kufogbe, 2012). In order to better contextualise LULC change and its social and environmental impacts, an intimate understanding of local perceptions of landscapes is required. Local knowledge is now accepted as a critical research component that can help fill the gap in our understanding on how to mitigate against, and adapt to, structural changes (Bollig \& Schulte, 1999; Makondo \& Thomas, 2018; Mistry \& Berardi, 2016; Reed, Dougill, \& Taylor, 2007).

The present study defines local knowledge following Raymond et al. (2010), who demarcate it from scientific knowledge through its recognition of local nuances, often left unnoticed by external experts who generate their knowledge through formalized processes rather than traditional norms and recently experienced human-environment interactions (C. D. Becker \& Ghimire, 2003; Olsson \& Folke, 2001).

It is widely accepted that the integration of local knowledge and remote sensing can provide new insights (Herrmann, Sall, \& Sy, 2014; Zaehringer, Llopis, Latthachack, Thein, \& Heinimann, 2018) and further holds the potential to upturn popular narratives on forest and land degradation that place the blame squarely on the land users (Fairhead \& Leach, 1995). In general, a high correspondence can be found between conventionally-classified LULC change and local perceptions, as shown, for instance, by Ariti, van Vliet, \& Verburg (2015).

However, the overall objective of most studies dealing with both local and scientific knowledge is to assess the reliability of stakeholders' perceptions by comparing it with conventional approaches rather than by integrating both sets as equivalent sources of information, though each one might have specific features and contain certain pitfalls (e.g. Delgado-Aguilar, Hinojosa, \& Schmitt, 2019; Eddy et al., 2017). In order to foster the latter integrative approach, this study is based on the recognition of local knowledge as a sound and reliable source of information on LULC change (Del Rio, Groot, DeClerck, \& EstradaCarmona, 2018). It thus includes local knowledge and environmental perception as the basis for the definition, training and validation of LULC classes. As people whose livelihoods depend directly on their natural environmental resources are understood as local experts, a participatory approach frames the entire research design.

In the face of future environmental change, the demand for knowledge on site-specific adaptations strategies and management guidelines are considered to be increasingly important. A perspective on past human-environmental pathways adds further value as it helps to illuminate the reasons behind processes of change and adaptation. This study aims at identifying LULC changes and their drivers in the sub-Saharan dryland of Pokot Central, Kenya, over a time frame of three decades. To better understand the underlying processes, it asks the following questions:

- What LULC changes can be observed in the study area between 1986 and 2017?

- What processes are driving these changes and how are they influenced by local perceptions and values?

- How can local knowledge be integrated into remote sensing and thus become key to contextualize LULC change?

As case-study a remote dryland region of Kenya was chosen. While LULC change has been studied in neighbouring regions (Egeru et al., 2015; Nyberg et al., 2015), the lowlands of Pokot Central have largely been neglected, though the area typifies many of the livelihood possibilities and constraints faced by communities in sub-Saharan drylands. It is therefore a representative case study to derive appropriate adaptation strategies that offer rural communities more sustainable and desirable development pathways.

\section{I DATA AND METHODOLOGY}

The drylands of Pokot Central (West Pokot County) in northwestern Kenya are a border region with several ethno-linguistic groups, located at a distance of $350 \mathrm{~km}$ to Nairobi (Figure 1). The study area is located between $1^{\circ} 24^{\prime}$ and $1^{\circ} 48^{\prime} \mathrm{N}$ (latitude) and $35^{\circ} 25^{\prime}$ and $35^{\circ} 41^{\prime} \mathrm{E}$ (longitude) and comprises approximately $705 \mathrm{~km}^{2}$. The area 


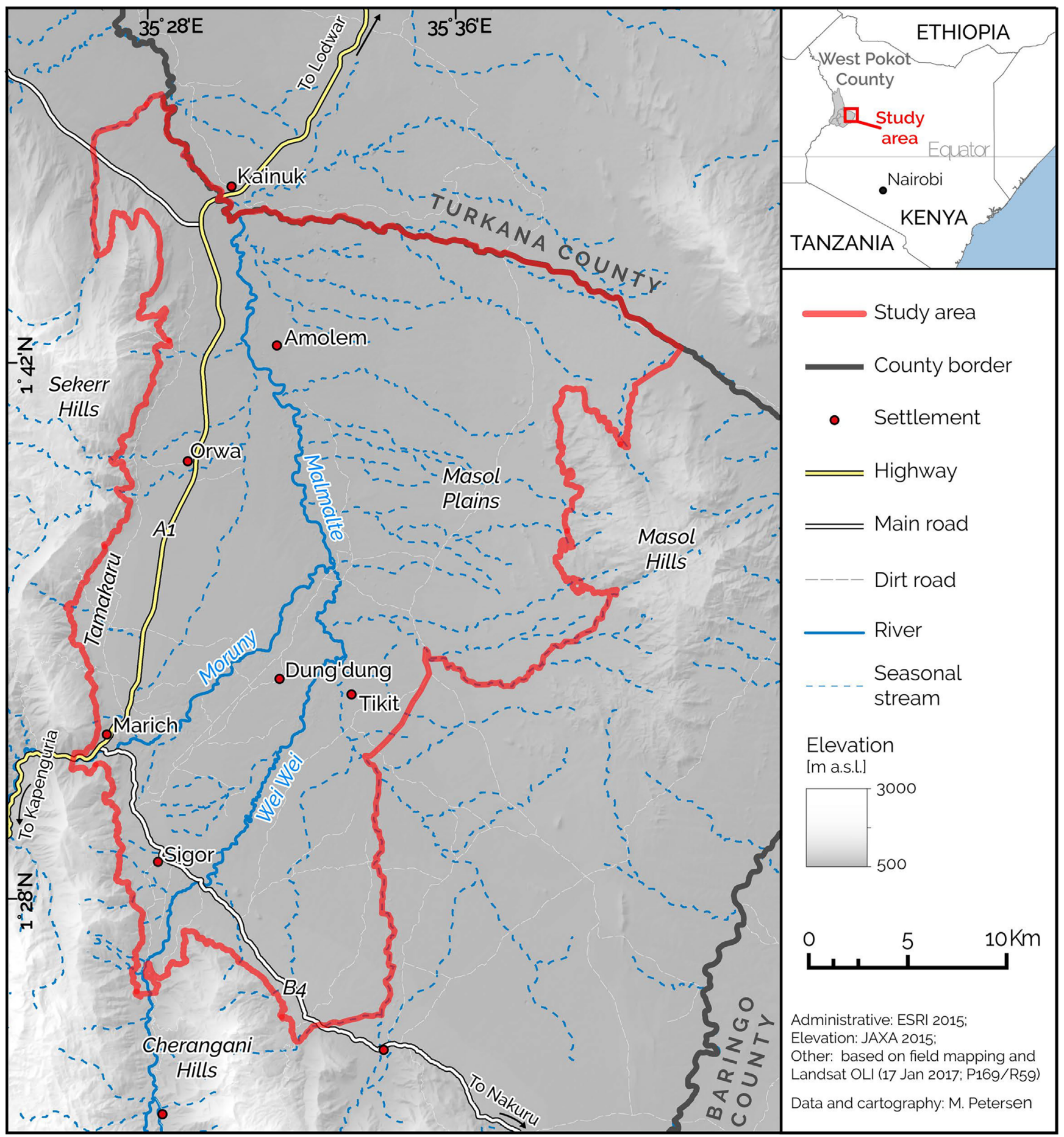

FIGURE 1 Topographic map of the study area in the Pokot Central region of West Pokot County (Kenya), with an indication of the hydrographic network, roads and settlements [Colour figure can be viewed at wileyonlinelibrary.com]

is bordered to the east, south and west by the Masol, Cherangani and Sekerr Hills, reaching altitudes of about 3,000 m a.s.l. Precipitation displays high interannual and spatial variability, ranging from $400 \mathrm{~mm}$ in the plains to $1,200 \mathrm{~mm}$ in the highlands, and is distributed over two rainy seasons (Geolnformatiks Ltd., 2017). The area is dominated by bush savanna mostly comprised of Vachellia tortilis (ForsSK.) GALASSO \& BANFI and Vachellia reficiens (WAWRA) KYAL. \& BOATWR. Rivers and seasonal streams are lined by gallery forests, while in some areas dense evergreen thickets of Euphorbia spp. occur. The A1 Highway between Kapenguria and Lodwar (the capitals of West Pokot County and Turkana County) is the area's only tarmacked connection with larger agglomerations of Kenya. While there are no urban areas, some basic facilities, including several small shops, weekly markets, health centres and a police station can be found in small centres such as, 
Marich, Tikit and Orwa (Figure 1). The administrative centre of Pokot Central is Sigor, the only settlement in the study areas that can be considered a town. Pokot Central is one of five sub-counties in West Pokot County, where the majority of the Pokot ethno-linguistic group lives. The land assigned to the Pokot also includes East Pokot subCounty in neighbouring Baringo County. According to census reports, population numbers in the district of Pokot Central increased from 43,159 inhabitants in 1989 to 119,016 in 2019 with a corresponding rise in population density from 21 to 58 persons $/ \mathrm{km}^{2}$ (Central Bureau of Statistics, 1994; KNBS, 2019). Livelihoods in the study area are based primarily on agro-pastoral land-use practices with increasing importance of small businesses or wage labour. During the 1990s, production of wood charcoal became a widespread source of income and has developed into a common part of many peoples' livelihood portfolio (Bergmann et al., 2019).

The methodological approach integrates qualitative social scientific assessments of local stakeholder knowledge through focus-group discussions (FGDs) and participatory mapping with quantitative groundvalidated remote sensing. Based on LANDSAT imagery from 1986, 1995, 2000, 2010 and 2017 (USGS, 2017; Table 1) long-term vegetation change was monitored. Owing to high inter-annual variation in plant phenology, the peak of the dry season around January was identified as the most appropriate time for analysis (Roden, Bergmann, Ulrich, \& Nüsser, 2016). In regions with relatively low or irregular

TABLE 1 Summary of satellite imagery, derived classification parameters and tested parameters

\begin{tabular}{|c|c|c|c|c|}
\hline Parameter & Description & Equation & Specifications & Reference \\
\hline $\begin{array}{l}\text { LANDSAT } \\
\text { bands }\end{array}$ & $\begin{array}{l}\text { Blue (B), Green (G), red (R), NIR, } \\
\text { SWIR1, SWIR2 }\end{array}$ & & $\begin{array}{l}28 \text { January 1986: } \\
\text { LANDSAT } 5 \text { TM } \\
\text { L1TP } \\
21 \text { January 1995: } \\
\text { LANDSAT } 5 \text { TM } \\
\text { L1TP } \\
27 \text { January 2000: } \\
\text { LANDSAT } 7 \text { ETM } \\
\text { L1TP } \\
30 \text { January 2010: } \\
\text { LANDSAT } 5 \text { TM } \\
\text { L1TP } \\
\text { 17 January 2017: } \\
\text { LANDSAT } 8 \text { OLI } \\
\text { L1TP } \\
\text { Path: 169; row: 59; } \\
30 \text { m resolution }\end{array}$ & (USGS, 2017) \\
\hline
\end{tabular}

Vegetation indices

\begin{tabular}{|c|c|c|c|c|}
\hline GNDVI & $\begin{array}{l}\text { Green normalized difference } \\
\text { vegetation index }\end{array}$ & $\frac{N \| R-G}{N \| R+G}$ & & $\begin{array}{l}\text { (Gitelson, Kaufman, \& Merzlyak, } \\
\text { 1996) }\end{array}$ \\
\hline SAVI & Soil adjusted vegetation index & $\frac{(\mathrm{NIR}-R) *(1+L)}{N I R+R+L}$ & Coefficient: $L=0.5$ & (Huete, 1988) \\
\hline \multicolumn{5}{|c|}{ Texture variables } \\
\hline Dissimilarity & & $\begin{array}{l}\sum_{i, j=0}^{N-1} i P_{i, j}|i-j| \\
\text { where: } \\
P_{i, j}=V_{i, j} / \sum_{i, j=0}^{N=0} V_{i, j} \\
\text { where } V_{i, j}=\text { value in cell } i(\text { row }) j \\
\quad \text { (column) of } \\
\quad \text { moving window and } N= \\
\quad \text { number of rows and columns }\end{array}$ & $\begin{array}{l}\text { Window size: } 3 \times 3 \\
\text { Offset distance: } 1 \\
\text { Grey level } \\
\quad \text { quantization: } 64 \\
\text { (Karlson et al. } 2015 \text { ) }\end{array}$ & (Lu \& Batistella, 2005) \\
\hline \multicolumn{5}{|c|}{ Transformations } \\
\hline TCT 1-3 & $\begin{array}{l}\text { Tasselled cap transformation } \\
\text { (Brightness }\left({ }_{1}\right) \text {, Greenness }(2) \\
\text { and Wetness }\left({ }_{3}\right) \text { ) }\end{array}$ & $\begin{array}{l}\mathrm{B}^{*} \mathrm{a}_{1 / 2 / 3}+\mathrm{G}^{*} \mathrm{~b}_{1 / 2 / 3}+\mathrm{R}^{*} \mathrm{c}_{1 / 2 / 3}+ \\
\mathrm{NIR}^{*} \mathrm{~d}_{1 / 2 / 3}+\mathrm{SWIR}^{*} \mathrm{e}_{1 / 2 / 3}+ \\
\mathrm{SWIR}^{*} \mathrm{f}_{1 / 2 / 3}\end{array}$ & $\begin{array}{l}\text { Coefficients a-f see } \\
\text { references }\end{array}$ & $\begin{array}{l}\text { (Baig, Zhang, Shuai, \& Tong, } 2014 \\
\text { (OLI); Crist, } 1985 \text { (TM); Huang, } \\
\text { Wylie, Yang, Homer, \& Zylstra, } \\
2002 \text { (ETM)) }\end{array}$ \\
\hline
\end{tabular}

\section{Tested vegetation indices}

Modified soil adjusted vegetation index (MSAVI: Qi, Chehebouni, Huete, Kerr, \& Sorooshian, 1994); Normalized difference vegetation index (NDVI: Rouse Jr, Haas, Schell, \& Deering, 1974); Ratio vegetation index (RVI: Jordan, 1969); Transformed vegetation index (TVI: Deering \& Haas, 1980); Thiam's transformed vegetation index (TTVI: Thiam, 1997)

Tested texture variables

Mean, variance, homogeneity. contrast, entropy, second moment, correlation (Haralick, Shanmugam, \& Dinstein, 1973; Lu \& Batistella, 2005) 
temporal availability of suitable LANDSAT imagery, such as in East Africa, changes are best detected through a post-classification comparison (Banskota et al., 2014). The accuracy of such a pixel-by-pixel comparison depends on the quality of initial classifications since errors are compounded in the final output. However, given a qualified sample of training and validation data, this approach offers the advantage to support the generation of 'from-to' matrices that register detailed quantitative information of detected land-cover change, which can be visualized on easy-to-interpret maps (e.g. Biro, Pradhan, Buchroithner, \& Makeschin, 2011; Kamusoko \& Aniya, 2009; Petit \& Lambin, 2002).

\section{1 | Focus-group discussions}

To integrate local knowledge in the study from the beginning, eight FGDs were conducted over one to 3 days each, between March 2017 and January 2019. They were facilitated by four experienced Pokot field assistants and involved between three and seven individuals from the study area, representing an age- and gender-sensitive cross section of the community (Table 2). The purpose of the FGDs was to identify and map locally recognized land-cover classes, assess their criteria of differentiation, gather narratives of socio-environmental change and discuss daily practices as well as the perceived value of individual land-cover classes. During FGDs, notes were taken and later transcribed and coded in MaxQDA. In order to identify different LULC classes, participatory mapping was conducted in three FGDs following the same semi-standardized procedure. For this purpose, characteristic photographs of a broad range of vegetation types were presented to all participants. These photographs had been taken during earlier field surveys, with the guidance of local rangeland scouts. Afterwards, the participants discussed the characteristics and categorized their own LULC classes. The Pokot names for LULC classes were used throughout the study and during all further

TAB LE 2 List of focus-group discussions (FGD) between 2017 and 2019 with details on the participants and discussed topics

\begin{tabular}{|lllll}
\hline FGD & $\begin{array}{l}\text { Date } \\
\text { (duration) }\end{array}$ & $\begin{array}{l}\text { Number of } \\
\text { participants } \\
\text { (women) }\end{array}$ & $\begin{array}{l}\text { Sources of } \\
\text { income }\end{array}$ & $\begin{array}{l}\text { Discussed } \\
\text { topics, } \\
\text { methods }\end{array}$ \\
\hline FGD1 & $03 / 2017$ (3d) & $5(4)$ & P, C, F & EC, CCP, R \\
\hline FGD2 & $03 / 2017$ (1d) & $4(0)$ & P & EC \\
\hline FGD3 & $11 / 2017$ (3d) & $6(2)$ & P, F, C & $\begin{array}{r}\text { EC, CCP, } \\
\text { PM, FS }\end{array}$ \\
\hline FGD4 & $11 / 2017$ (3d) & $7(2)$ & P, F, C, B & $\begin{array}{r}\text { EC, CCP, } \\
\text { PM, FS }\end{array}$ \\
\hline FGD5 & $12 / 2017$ (3d) & $6(4)$ & P, F, C, B, & $\begin{array}{r}\text { EC, CCP, } \\
\text { PM, FS }\end{array}$ \\
\hline FGD6 & $12 / 2018$ (1d) & $3(3)$ & C, B, & CCP \\
\hline FGD7 & $01 / 2019$ (1d) & $5(0)$ & P, F, C, E & EC, CCP, R \\
\hline
\end{tabular}

Note: Abbreviations for participants' occupations: P, pastoralists; C, charcoal producer; F, farmer; B, business owner; G, gold panning; FW, firewood seller; Abbreviations for covered topics: $E$, FGD only with village elders; $\mathrm{CCP}$, charcoal production; EC, environmental change; $\mathrm{R}$, rules and regulations; $\mathrm{PM}$, participatory mapping; $\mathrm{FS}$, future scenario conversations as an expression of appreciation of their knowledge. In the next step, a large-size print of the most recent LANDSAT scene from 2017 was presented to the group. As participants were unfamiliar with maps, they had to be introduced to satellite imagery by trained research assistants. Together they identified, distinguished and delineated specific areas, such as the approximate location of their homesteads, grazing grounds, water ponds, seasonal streams and settlements. Subsequently, the group was split into subgroups to colour- or number-code the previously developed LULC classes on older LANDSAT scenes. Additions and changes could be made during a final plenary session. The repetition of this procedure during three workshops made it possible to identify LULC classes and their locations, agreed upon by all participants.

\section{2 | Training and validation of remote sensing data}

Training and validation of remote sensing data was derived from field surveys, local stakeholder knowledge and additional very-high-resolution (VHR) image data (Table 3). During two field campaigns in January 2016 and February-March 2017, a total of 93 sample plots $\left(50 \times 50 \mathrm{~m}^{2}\right)$ were selected based on a stratified random sampling strategy, with support of a knowledgeable local informant. Approximately $30 \%$ of these plots were revisited after heavy rains in November-December 2017 to document seasonal precipitation effects on land-cover dynamics. This was particularly important to distinguish permanent bare ground from seasonal grasslands and to detect differences in the density of the herbaceous understory layer in bushy areas during the rainy season.

After some of the delineated classes from the FGD exercise were combined following Mialhe et al. (2015), thresholds were defined to allow operationalization and comparison with remote sensing procedures. The resulting LULC classes and their spatial distribution were used for training and validation of classifications, especially of older LANDSAT images. Wherever possible, visual interpretation of VHR datasets including World View, QUICKBIRD and Google Earth data as well as historical aerial photographs were used for cross-checking and contextualization (Table 3).

\section{3 | Image classification}

Image pre-processing and classification were conducted in $\mathrm{R}$ (R Development Core Team, 2008). The analysis comprised a 17-band composite stack of visual, near- and shortwave infrared bands, spectral vegetation indices $(\mathrm{VI})$ and texture measures for each timestep (Table 1). These were used for the final image classification using nonparametric Random Forest (RF) classifier (Breiman, 2001) through the R function superClass (Leutner \& Horning, 2017). This machinelearning algorithm has already been successfully employed for landcover classifications (Adam, Mureriwa, \& Newete, 2017; Gislason, Benediktsson, \& Sveinsson, 2006; Rodriguez-Galiano, Ghimire, Rogan, Chica-Olmo, \& Rigol-Sanchez, 2012; Zoungrana et al., 2015). In order to better understand classification errors and misclassifications 
TABLE 3 Additional data sources used to train the image classification

\begin{tabular}{|c|c|c|c|c|c|}
\hline Image type & Image source & Date & Resolution & Extent & Training for \\
\hline SENTINEL 2 & ESA 2017 & 12 January 2017 & $10 \mathrm{~m}$ & $705 \mathrm{~km}^{2}$ & 2017 \\
\hline Google Earth & Google Inc. 2017 & May/June 2017 & & $300 \mathrm{~km}^{2}$ & 2017 \\
\hline Google Earth - historical & Google Inc. 2017 & 2013 & & & 2010 \\
\hline VHR QUICKBIRD & Digital Globe 2017 & 10 December 2011 & $0.6 \mathrm{~m}$ & $100 \mathrm{~km}^{2}$ & 2010 \\
\hline Historical aerial images ${ }^{a}$ & Royal Air Force; Hunting Aerosurveys Ltd. & 1950s-1970s & $\begin{array}{l}1: 50,000 \\
1: 12,500\end{array}$ & & 1986 \\
\hline
\end{tabular}

Note: Collected training data: $4.5-9 \mathrm{~km}^{2}$

${ }^{a}$ Available through Bodleian Libraries of the University of Oxford

between scenes, an additional accuracy assessment (Congalton, 1991; Story \& Congalton, 1986) using a previously separated set of validation data was conducted for all scenes.

\section{4 | Change detection}

Subsequently, the oldest and newest scene (1986/2017) were compared on a pixel-by-pixel basis. The 'from-to' changes were quantified in change matrices (SI 2.1; for changes between successive timesteps see SI 2.2-SI 2.5) and classified into four change classes: deforestation, decrease in canopy cover, increase in canopy cover and other/no changes. Only transitions between two clearly distinguishable LULC classes were considered significant (Figure 4). For example, the change between the LULC class 'open to closed woodland' and 'sparsely vegetated areas' for example was considered too subtle and might be due to slight changes in plant phenology associated with rainfall variability. These changes were thus classified as 'other changes' and grouped together with 'no change' (Figure 4).

A drawback of post-classification change detection is the accumulation of classification errors in the final product (Congalton \& Green, 2019, pp. 233-246). In order to estimate this error, an additional accuracy assessment was conducted for detected changes between 1986 and 2017. For this purpose, a total of 199 random points were generated. LULC classes for the 1986 and 2017 scenes were visually interpreted and their transition (e.g. gallery forest in 1986 to bare area in 2017) classified into one of the five change classes (e.g. deforestation). The visually interpreted change detection was then used for the accuracy assessment. A more detailed workflow of data analysis in the context of image classification and change detection is provided in the Appendix S1 (SI 1.1-SI 1.3).

\section{3 | RESULTS}

\section{1 | Land-use and land-cover classes}

During the FGDs nine LULC classes were identified, described and mapped (Figure 2). Participants were able to distinguish LULC classes by small differences in species composition, herbal layer and phenological characteristics. Due to the relatively low spatial resolution of LANDSAT images, open (wuw nyo tartar) and closed (wuw nyo anger) woodland were combined into one class. Wuw nyo kieghe, a special type of woodland where all trees are the same height, belong to one species and allow almost no herbal layer, is also included in this class. Farmland (paren) is not separated into irrigated or rain-fed but could be further specified by its location next to a river (paren pa lalwa) or close to a homestead (paren po kiror).

\section{2 | Image classification and change detection}

Image classification reveals a dynamically changing mosaic of woodand grasslands across the study area (Figure 3). In 1986, half (51\%) of the area was covered by open to closed woodlands while $27 \%$ were grasslands. This LULC class was typically found in areas with a loose, sandy soil, as prevalent in the Masol Plains but also on several alluvial fans west of the A1 highway (tamakaru) and some smaller ones along the foot slopes of the Cherangani Hills. Another $16 \%$ were comprised of Euphorbia spp. thickets and $4 \%$ of gallery forest along the main rivers, covering a larger area between Marich, Sigor and Tikit.

In the 2017 scene, which has the highest overall accuracy and the most reliable training and validation data, many patches along the rivers were classified as bare areas or farmland. Bare areas are particularly noteworthy, as they increased almost fivefold from 1.3\% in 1986 to $8 \%$ in 2017. Grassland is only found in small patches in the Masol Plains (7\%) while open to closed woodlands dominate the scene by $71 \%$. Field observations have shown that bare areas along the rivers are usually sandy riverbeds, indicating an increased vulnerability to flood erosion or fallow farms. Many fields were harvested shortly before the LANDSAT image acquisition in January but not yet tilled again. Furthermore, the Sigor irrigation scheme reached its third phase of expansion in December 2016, explaining the large patch of bare ground north of the farmlands at Sigor. This irrigation scheme was implemented in 1987 by the Government of Kenya, in cooperation with Italian partners.

Whereas the overall accuracies for the 2000 and 2017 classification are very high ( $95 \%$ and $97 \%$ respectively; Table 4 ), those for the 


$\begin{array}{llll}\text { LULC } & \text { Characteristics } & \begin{array}{l}\text { Pokot } \\ \text { name }\end{array} & \text { Explanation }\end{array}$

\begin{tabular}{|c|c|c|c|c|}
\hline $\begin{array}{l}\text { Gallery } \\
\text { forest }\end{array}$ & $\begin{array}{l}\text { Height }>10 \text { m; Canopy cover }>70 \% \text {; } \\
\text { dominantly single stemmed trees; } \\
\text { with/without subcanopy layer; } \\
\text { impenetrable in some parts } \\
\text { (Vachellia tortilis (Forssk.) Galasso \& } \\
\text { Banfi.) }\end{array}$ & $\begin{array}{l}\text { Wuw po } \\
\text { lalwa }\end{array}$ & $\begin{array}{l}\text { Larger communities of } \\
\text { mostly higher trees } \\
\text { along the rivers }\end{array}$ & 8 \\
\hline Thicket & $\begin{array}{l}\text { Height <10 m; canopy cover > } 70 \text { \%; } \\
\text { impenetrable; with dense } \\
\text { subcanopy layer; evergreen } \\
\text { (Euphorbia spp.) }\end{array}$ & Skwür & $\begin{array}{l}\text { Impenetrable mix of } \\
\text { short trees and shrubs, } \\
\text { 'one cannot see through' }\end{array}$ & \\
\hline \multirow{3}{*}{$\begin{array}{l}\text { Woodland } \\
\text { (continuum } \\
\text { from open } \\
\text { to closed) }\end{array}$} & \multirow{3}{*}{$\begin{array}{l}\text { Height }<10 \text { m; canopy cover } 15-70 \% \text {; } \\
\text { with scattered larger trees; single- } \\
\text { but mostly multi-stemmed trees; } \\
\text { with subcanopy layer; deciduous } \\
\text { (Vachellia spp.) (Where dominated } \\
\text { by multi-stemmed, deciduous } \\
\text { Vachellia reficiens (Wawra) Kyal. \& } \\
\text { Boatwr. usually no subcanopy layer) }\end{array}$} & $\begin{array}{l}\text { Wuw nyo } \\
\text { anger }\end{array}$ & $\begin{array}{l}\text { Dense mix of short trees } \\
\text { and shrubs, with few } \\
\text { larger trees in between, } \\
\text { where you can hardly } \\
\text { walk through and where } \\
\text { people would not settle }\end{array}$ & \\
\hline & & $\begin{array}{l}\text { Wuw nyo } \\
\text { tartar } \\
\text { (also: } \\
\text { Sarsar) }\end{array}$ & $\begin{array}{l}\text { A bushy area where you } \\
\text { can easily walk through } \\
\text { and where people settle; } \\
\text { often a mixture of tall } \\
\text { and short trees with foot } \\
\text { trails in between }\end{array}$ & \\
\hline & & $\begin{array}{l}\text { Wuw nyo } \\
\text { kieghe }\end{array}$ & $\begin{array}{l}\text { The trees are all the } \\
\text { same height, and } \\
\text { nothing grows below }\end{array}$ & \\
\hline $\begin{array}{l}\text { Sparsely } \\
\text { vegetated }\end{array}$ & $\begin{array}{l}<15 \% \text { cover, very scattered } \\
\text { trees/bushes; no grass layer }\end{array}$ & Nameywa & $\begin{array}{l}\text { Vegetation is very } \\
\text { scattered and appears in } \\
\text { small 'islands' of an } \\
\text { individual tree and some } \\
\text { shrubs;' no grass appears } \\
\text { after the rains }\end{array}$ & \\
\hline Grassland & $\begin{array}{l}\text { Cover of woody plants }<15 \% \text {; annual } \\
\text { grassland }\end{array}$ & Korosus & $\begin{array}{l}\text { An area where you find } \\
\text { plenty of grass }\end{array}$ & \\
\hline Farmland & Cultivated fields & Paren & $\begin{array}{l}\text { Farmed land, no } \\
\text { differentiation between } \\
\text { irrigated and rainfed }\end{array}$ & \\
\hline Bare areas & $\begin{array}{l}\text { Land with limited vegetation, such } \\
\text { as sandy or rocky riverbeds, } \\
\text { wasteland, land recently cleared for } \\
\text { future farming or recently harvested } \\
\text { farmland }\end{array}$ & Korron & $\begin{array}{l}\text { Bare ground, nothing } \\
\text { grows, no grass appears } \\
\text { after the rains }\end{array}$ & 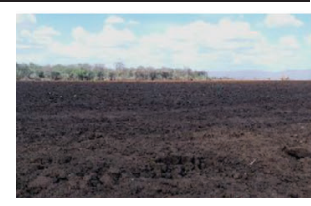 \\
\hline
\end{tabular}

FIGURE 2 Land-use and land-cover (LULC) classes for Pokot Central as defined in participatory workshops, and used for LUCC classification of LANDSAT remote sensing images in this study [Colour figure can be viewed at wileyonlinelibrary.com] 

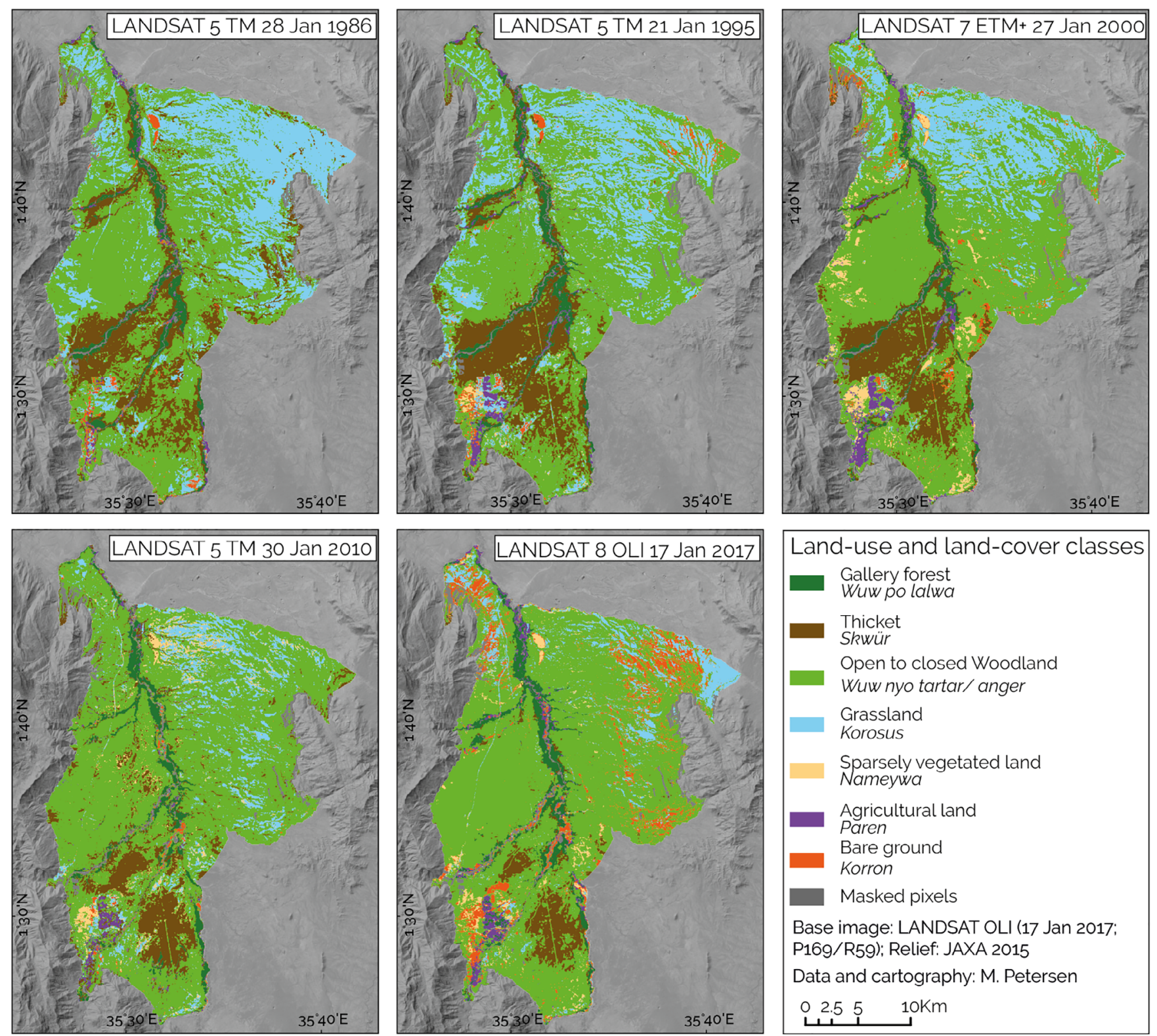

\begin{tabular}{|l|}
\hline Land-use and land-cover classes \\
Gallery forest \\
Wuw po lalwa \\
Thicket \\
Skwür \\
Open to closed Woodland \\
Wuw nyo tartar/ anger \\
Grassland \\
Korosus \\
Sparsely vegetated land \\
Nameywa \\
Agricultural land \\
Paren \\
Bare ground \\
Korron \\
Masked pixels \\
Base image: LANDSAT OLI (17 Jan 2017: \\
P169/R59); Relief: JAXA 2015 \\
Data and cartography: M. Petersen \\
O 2.5 5 10Km \\
1.
\end{tabular}

Year

1986

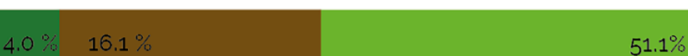

$26.4 \%$

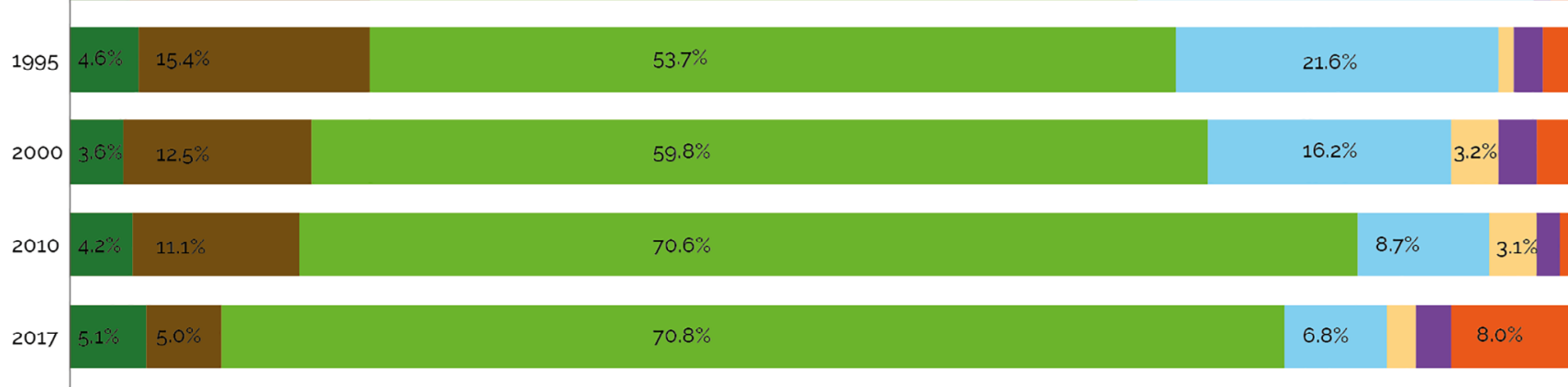

0\%

$100 \%$

FIGURE 3 Land-use and land-cover (LULC) classification for Pokot Central in 1986, 1995, 2000, 2010 and 2017 based on LANDSAT images (path 169, row 59), and the resulting percent distribution values for each LULC class; see Table 4 for the corresponding absolute values [Colour figure can be viewed at wileyonlinelibrary.com] 


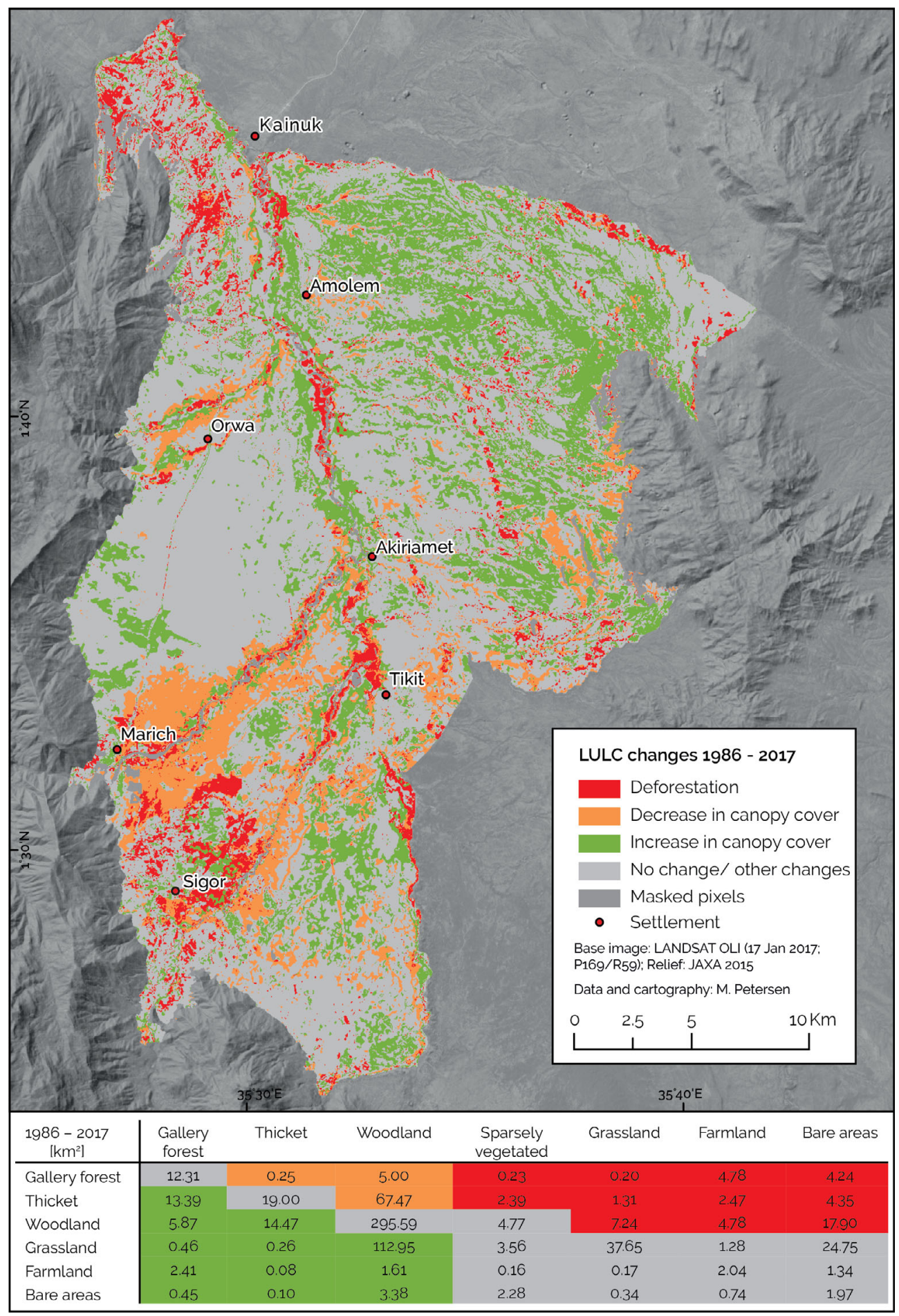

FIGURE 4 Total land-use and land-cover change in Pokot Central between 1986 and 2017, with change matrix colour-coded in accordance with the four defined classes of change [Colour figure can be viewed at wileyonlinelibrary.com]

remaining scenes are lower but still within an acceptable range (1986:87\%; 1995:89\%; 2010:78\%; for detailed accuracies: SI 3.1-3.5).

Change detection between 1986 and 2017 reveals significant shifts in vegetation cover for $41 \%$ of the study area (Figure 4). While deforestation was observed in an area of $50 \mathrm{~km}^{2}$ (18\% of detected changes), a decrease in canopy cover was detected in a total area of $73 \mathrm{~km}^{2}$ (26\% of detected changes). The most prevalent transformation was the increase in canopy cover in an area of $155 \mathrm{~km}^{2}$ (56\% of detected changes), most of which $\left(114 \mathrm{~km}^{2}\right)$ is associated with bush encroachment into former grasslands. A striking example can be found in the Masol Plains, where homogenous communities of $V$. reficiens with little to no herbaceous or grass layer are now dominating former pastures.

Hotspots of forest and woodland thinning are located in the vicinity of Marich, Sigor and Tikit (Figure 4). Around these more densely populated areas, thickets have widely been transformed into open to closed woodlands (67.5 $\mathrm{km}^{2}$ or $61 \%$; SI 2.1). Field observations and participatory analysis of the LULC classifications, confirm that 
TABLE 4 Areal distribution (in $\mathrm{km}^{2}$ ) of the seven main land-cover classes in the study area, during January in each of 5 years $(1986,1995,2000,2010$ and 2017), and the total net change from 1986 to 2017 (see SI 2.2-SI 2.5 for change matrices between successive timesteps)

\begin{tabular}{|c|c|c|c|c|c|c|}
\hline & \multirow{2}{*}{$\frac{\text { Area }\left(\mathrm{km}^{2}\right)}{1986}$} & \multicolumn{5}{|c|}{ Net changes $\left(\mathrm{km}^{2}\right)$} \\
\hline & & 1995 & 2000 & 2010 & 2017 & $1986-2017$ \\
\hline Gallery forest & 27.15 & 31.66 & 24.86 & 28.74 & 34.92 & +7.77 (29\%) \\
\hline Thicket & 110.45 & 105.62 & 85.52 & 76.17 & 34.16 & $-76.29(69 \%)$ \\
\hline Woodland & 350.70 & 368.42 & 410.33 & 484.33 & 486.09 & +135.39 (39\%) \\
\hline Sparsely vegetated & 0.00 & 6.70 & 21.89 & 21.60 & 13.38 & +13.38 \\
\hline Grassland & 180.93 & 147.99 & 110.92 & 59.85 & 46.92 & $-134.01(74 \%)$ \\
\hline Farmland & 7.81 & 13.36 & 17.56 & 10.85 & 16.11 & $+8.30(106 \%)$ \\
\hline Bare areas & 9.25 & 12.76 & 15.13 & 4.65 & 54.59 & +45.34 (490\%) \\
\hline Overall accuracy & 0.87 & 0.89 & 0.95 & 0.78 & 0.97 & \\
\hline
\end{tabular}

deforestation is mostly associated with agricultural expansion. Along both the Wei Wei and the Moruny River, gallery forests and thickets have been cleared for irrigated farming, now covering $16 \mathrm{~km}^{2}$ across the whole study area (Table 4).

As errors in LULC classification accumulate in the postclassification change detection, the accuracy assessment of the change detection shows a larger error than those for the single scenes. The overall accuracy of the change detection is $60 \%$, while the lowest user's accuracy was $50 \%$ and the lowest producer's accuracy was $40 \%$, both calculated for the change class of decrease in canopy cover.

\section{3 | Drivers of change}

Unlike the data in the remote sensing analysis, the qualitative nature of the data obtained from FGDs and related participatory methods does not allow for a quantifiable comparison of driving factors. The LULC class 'thickets' shows a pronounced decline between 1986 and 2017 (by 69\%; Table 4). This LULC class has "no importance for the people' and is perceived as dangerous because of the wild animals living there (FGD3). Families would clear the area close to their homestead or fields to avoid encounters with these animals (FGD3). Therefore, the large reduction in thickets is explained mainly by the expansion of human settlements, especially in the triangle between Marich, Sigor and Tikit (Figure 4).

The most prevalent change observed in the image analysis is the encroachment of bushes into former grasslands. These former pastures are now vastly dominated by two species of Vachellia. While the majority of the Masol Plains have been encroached by $V$. reficiens, Tamakaru is covered almost exclusively with $V$. nubica. Typical for both is the almost complete absence of an herbal layer and existence of homogenous tree height. Locals have repeatedly mentioned the increase of these species as '[V. nubica] is everywhere' (FGD1). They evaluated its expansion as a degradation of former pastures and identified overgrazing, reduction in rainfall (FGD2) and introduction of Vachellia seeds into the grasslands through smallstock (FGD6) as main drivers. Another important factor brought up by the respondents is the discontinuation of traditional pasture burning due to its banning by government decree in the 1980s (FGD3).

The increase of sparsely vegetated areas is characteristic for woodlands that have been thinned out, typically around settlements. Population growth and the increased demand for wood for building and fuel was also identified as a driving factor for the thinning of bushland by FGD participants (FGD3, FGD5, FGD6). However, most people were said to leave some trees and bushes on their homesteads and tend to them 'because the shade is needed for kids [young children] and small animals' (FGD7). Except for the surroundings of Sigor Centre, where there is almost no vegetation left, at other rather densely populated villages, such as Marich or Tikit, some fractional vegetation cover remains.

Gallery forests were identified as a valued LULC class by local stakeholders, especially due to its ability to limit flood erosion (FGD3) and owing to the higher prevalence of $V$. tortilis, which provides much needed leaves and pods that are valued as nutritious livestock fodder (FGD3, FGD5). Thus, informal regulations exist to protect these forests (FGD4, FGD7), even though wood from these forests are most preferred for charcoal production, building material and beehive construction (FGD5). Nevertheless, competing resource use for woodbased forest products and expansion of land for crop cultivation has led to deforestation along rivers. The from-to change matrix between 1986 and 2017 (SI1) shows many patches of gallery forest that have been transformed into agricultural land or bare areas (with a dominance of bare fields according to field observations). However, locals do not usually mention the expansion of agriculture as a driver of deforestation. It was even stated, that 'as long as the intention is to farm, the clearing of the bush is not a problem with the government' (FGD3). Only when they were asked directly for the effects of clearings for agriculture, participants agreed that cutting of trees along the rivers is worse than further away from it, because 'it has more negative effects on soil and the river' (FGD3). It was also explained that farming too close to the river is responsible for the widening of the riverbed with farmland often being swept away during floods in the rainy season (FGD3). Nevertheless, agricultural land is perceived very positively, with only the unreliability of the harvests and the prevalence of crop pests considered to be a negative feature of this land-use class (FGD3). There was a considerable downside to gallery 
forests in that they provide cover to wild animal pests (porcupines, antelope, monkeys and elephants), which invade and destroy riverinebased crop fields (FGD3). Despite local demands for arable land, the net amount of gallery forests remained comparatively stable between 1986 and 2017. While one explanation for this is that up until recently, shifting cultivation was a common practice, also the abandonment of Amolem (Figure 1) due to conflict (FGD3), allowed forest regeneration in this area.

In addition to increased settlements and farming, local stakeholders regularly mention wood extraction for charcoal production as an important driver of tree cover loss (FGD2, FGD6). Image analysis, however, does not reveal a correlation between a decrease in vegetation cover and charcoal production hotspots along the A1 highway (Bergmann et al., 2019). But while the low spatial resolution of LANDSAT data cannot offer details on species composition, local respondents observed that in certain areas trees used for charcoal production are almost gone' (FGD6). As tree species most preferred for charcoal production, respondents named V. reficiens, V. tortilis, Senegalia mellifera (M. VAHL) SEIGLER \& EBINGER and Vachellia nubica BENTH. (FGD5, FGD6, FGD7) though informal rules aim at protecting the more valued tree species (FGD1, FGD4, FGD6). Other drivers of change include wood extraction for timber (FDG2, FGD5) and the felling of trees by elephants (FGD2).

\section{4 | DISCUSSION}

LULC change in the drylands of Pokot Central shows dynamic pathways over the past three decades. A better understanding of driving forces requires an analysis of local histories of development and human-environmental interactions.

Our change detection analysis revealed that the most prevalent change between 1986 and 2017 in the study area is the increase in woody vegetation at the expense of grassland. The phenomenon of bush encroachment or 'green desertification' has been observed in several regions across sub-Saharan Africa (M. Becker et al., 2016; Liao, Clark, \& DeGloria, 2018; Venter, Cramer, \& Hawkins, 2018). The introduced tree Prosopis juliflora plays a major role in this process in many East African drylands (Shiferaw et al., 2019), including Baringo and Turkana County, both located in close proximity of Pokot Central (Maundu, Kibet, Morimoto, Imbumi, \& Adeka, 2009; Mwangi \& Swallow, 2005). However, only isolated specimens of this particular tree species were found in the present study. For the adjoining plains of East Pokot, located in Baringo County, Vehrs (2016) also reported a transformation from grasslands to Vachellia-dominated woodlands starting in the 1950s, based on oral evidence. Likewise, in the study area, this process was already detected in the Masol Plains for the time between 1973 and 1978 by Conant (1982), who identified reduced rains and changing management regimes as main drivers based on analysis of early LANDSAT imagery. A series of violent conflicts, droughts and government regulations had led to the nearcomplete abandonment of the Masol Plains in 1976 (Roden \& Bergmann, 2015; Zaal, van Tienhoven, \& Schomaker, 1985). The present study traces an intensification of the process of bush encroachment between 1986 and 2017 and temporally and spatially expands the underlying causes of reduction in annual rainfall, overgrazing and the lack of pasture burning. These findings are similar to studies in other regions of Africa that identify a correlation between woody plant proliferation with changing rainfall patterns and reduction in the use of fire for pasture management (de Klerk, 2004; Stevens et al., 2017). Reduced mobility of pastoralist communities has recently been discussed thoroughly by Liao et al. (2020) as a crucial cause of dryland degradation and unsustainable rangeland management.

Abandonment of former grazing areas is one of several factors that forced the Pokot to adjust their cattle-centred economic and cultural fabric to altered structural conditions from the mid-1980s onwards (Bollig, 2016). An increasing importance of sedentary and market-oriented small-stock keeping, especially of goats, and 'the adoption of farming as a key element in the overall process of economic diversification' are identified as dominant regional trends (Österle, 2008). Several projects by the Kenyan Government and international partners are furthering this transition through the promotion of modern irrigation farming (Adams, 1990; Government of the Republic of Kenya, 2012; Mugova \& Mavunga, 2000) even though the expansion of cropland is known to contribute to deforestation (Shiferaw et al., 2019). In the present study, increased settlements and farming were found to be the main drivers for deforestation and decrease in forest cover. However, LULC change is also affected by cultural perceptions and values as has been demonstrated in the massive decline of thickets that are deemed dangerous, while food provision is regarded as the most relevant service a LULC class can deliver to local communities.

Repeatedly mentioned by respondents as a driver of negative environmental change, was the production of wood charcoal which was widely adopted as a source of income by people in the study area since the 1990s. These people were forced to adopt this activity as a consequence of conflict, displacement and socio-economic change (Roden \& Bergmann, 2015). Many studies in other areas report the harmful effects of wood extraction for commercial charcoal production on woodland resources (Kutsch et al., 2011; Rembold, Oduori, Gadain, \& Toselli, 2013; Sedano et al., 2016). The LANDSAT analysis, however, does not reveal such a link in our study area. In contrast to findings by Kiruki, van der Zanden, Malek, \& Verburg (2017) from Kitui County in southeastern Kenya, increased charcoal production in areas of decreased canopy cover cannot be observed. It can be assumed that the scale of charcoal production in Pokot Central is still at a level where environmental effects are not as pronounced as in primary production regions such as Kitui County and are thus currently not observable with the spatial resolution of LANDSAT imagery. The local perceptions give a more fine-grained picture on decreasing tree species, though they could also be clouded by a widespread negative image of this activity (Mwampamba, Ghilardi, Sander, \& Chaix, 2013). Respondents stated that the encroaching V. reficiens is predominantly cut as wood for charcoal production while efforts are made to try to preserve trees that are more valuable for livestock. This can be interpreted as an adaptation strategy by local communities that should be taken into consideration by higher-level 
decision-making actors in government. Similarly, Oduor \& Githiomi (2013) prescribe community management of invasive $P$. juliflora in Baringo, Kenya as one means to control its spread whilst securing a livelihood for local inhabitants. Further developments of this activity, however, should be closely monitored, as an expected growing demand for wood charcoal could alter local practices and rapidly increase the pressure on woodland resources (Taylor, Wanjiru, Johnson, \& Johnson, 2020). A marked empathy for local producers, as well as consideration of their knowledge and development solutions are crucial for successful management.

The present study further promotes the integration of local knowledge and remote sensing approaches. While a LULC-change analysis based on LANDSAT imagery has proven to be a solid scientific approach, subpixel changes may go undetected. At the same time, the drivers of LULC change can only partially be reconstructed using remote sensing approaches as stand-alone technique. While the correlation between deforestation and agricultural expansion can be made based on multitemporal image analysis alone, the complexities of canopy increase in former grasslands as well as the reasons behind agricultural expansion need ground-based information. Against this background, the study in Pokot Central adds to the growing number of studies that demonstrate the usefulness of integrating remote sensing techniques with local stakeholder knowledge (Del Rio et al., 2018; Egeru et al., 2015; Sulieman \& Ahmed, 2013). Chalmers \& Fabricius (2007) stress that ecological knowledge can be unevenly distributed among local communities and advise to carefully select local experts. They define those experts as people whose livelihoods are directly based on surrounding natural resources. As all respondents from the present study were either livestock keepers, farmers or both and had grown up in the study area they do fulfil this criterion. The broad ecological knowledge of the Pokot has also been confirmed by Wasonga, Ngugi, \& Kitalyi (2003). The present study takes local knowledge one level further into the remote sensing approach.

While most studies incorporate local knowledge at the end by comparison with results from remote sensing approaches or to add depths, here, local knowledge contextualized every step of the remote sensing analysis; from the delineation of LULC classes, collecting of training and validation data and finally the discussion of driving factors. Applying local terms and definitions facilitated discussions about changes, validation of results and communication of findings. It furthermore helped to understand the way the environment is categorized by the Pokot and their motivation to protect certain ecosystems or not. The integration of remote sensing and local knowledge provides a holistic view on LULC change in Pokot Central and offers a solid base for site-specific and actor-centred management approaches as will be needed for the sustainable development of drylands (Fu et al., 2021).

\section{5 | CONCLUSIONS AND POLICY IMPLICATIONS}

This study identifies LULC changes and their drivers in a sub-Saharan dryland over three decades between 1986 and 2017. Our integrated approach contextualizes remotely sensed LULC changes with local perceptions of land-cover categories and degradation processes. Bush encroachment into former grasslands was recognized as the most prevalent change, while deforestation and decrease in canopy cover occurred mainly in the context of agricultural expansion and increased settlements. By relying strongly on local land-user perceptions of LULC change, it was possible to not only identify changes and their drivers but also the intrinsic motivations of the local community to prefer certain LULC classes over others. This study helps to understand the linkages between environmental change and livelihood dynamics of dryland populations across historical developments. The consequent participatory approach employed in this study combines the delineation of locally perceived and accepted land-cover categories with a qualitative interpretation of the driving factors behind LULC change and land degradation. This combined approach helps to unravel the complexities of land-use decision making, and may therefore serve as a basis for future programs that aim to foster locally accepted adaptation strategies and management guidelines for sub-Saharan drylands.

\section{ACKNOWLEDGEMENTS}

Research for this paper was generously funded by the German Research Foundation (Deutsche Forschungsgemeinschaft, DFG) in the context of the project 'Producing Charcoal in the sub-Saharan Drylands: The Contested Fuelscape of Central Pokot, Kenya' (NU 102/14-1). Special thanks go to our respondents in Pokot Central for their hospitality and participation in our study, to our field assistants Nancy Kamurio, Dinah Kortom and Jacob Kiramwai and to the Marich Pass Field Studies Centre. We are thankful for the constructive comments by anonymous reviewers.

\section{CONFLICT OF INTEREST}

The authors declare no conflict of interest.

\section{DATA AVAILABILITY STATEMENT}

Data available on request from the authors.

\section{ORCID}

Marcus Nüsser (DD https://orcid.org/0000-0002-8626-8336

\section{REFERENCES}

Adam, E., Mureriwa, N., \& Newete, S. (2017). Mapping Prosopis glandulosa (mesquite) in the semi-arid environment of South Africa using highresolution WorldView-2 imagery and machine learning classifiers. Journal of Arid Environments, 145, 43-51. https://doi.org/10.1016/j. jaridenv.2017.05.001

Adams, W. M. (1990). How beautiful is small? Scale, control and success in Kenyan irrigation. World Development, 18(10), 1309-1323. https://doi. org/10.1016/0305-750X(90)90112-B

Anthonj, C., Diekkrüger, B., Borgemeister, C., \& Kistemann, T. (2019). Health risk perceptions and local knowledge of water-related infectious disease exposure among Kenyan wetland communities. International Journal of Hygiene and Environmental Health, 222(1), 34-48. https://doi.org/10.1016/j.ijheh.2018.08.003

Archer, S. R., Andersen, E. M., Predick, K. I., Schwinning, S., Steidl, R. J., \& Woods, S. R. (2017). Woody plant encroachment: Causes and 
consequences. In D. Briske (Ed.), Rangeland systems (pp. 25-84). Cham, Switzerland: Springer.

Ariti, A. T., van Vliet, J., \& Verburg, P. H. (2015). Land-use and land-cover changes in the central Rift Valley of Ethiopia: Assessment of perception and adaptation of stakeholders. Applied Geography, 65, 28-37. https://doi.org/10.1016/j.apgeog.2015.10.002

Baig, M. H. A., Zhang, L., Shuai, T., \& Tong, Q. (2014). Derivation of a tasselled cap transformation based on Landsat 8 at-satellite reflectance. Remote Sensing Letters, 5(5), 423-431. https://doi.org/10.1080/ 2150704X.2014.915434

Banskota, A., Kayastha, N., Falkowski, M. J., Wulder, M. A., Froese, R. E., \& White, J. C. (2014). Forest monitoring using Landsat time series data: A review. Canadian Journal of Remote Sensing, 40(5), 362-384. https:// doi.org/10.1080/07038992.2014.987376

Becker, C. D., \& Ghimire, K. (2003). Synergy between traditional ecological knowledge and conservation science supports forest preservation in Ecuador. Conservation Ecology, 8(1), 1. https://doi.org/10.5751/es00582-080101

Becker, M., Alvarez, M., Heller, G., Leparmarai, P., Maina, D., Malombe, I., ... Vehrs, H. (2016). Land-use changes and the invasion dynamics of shrubs in Baringo. Journal of Eastern African Studies, 10(1), 111-129. https://doi.org/10.1080/17531055.2016.1138664

Bergmann, C., Roden, P., \& Nüsser, M. (2019). Contested fuelscapes: Producing charcoal in sub-Saharan drylands. Area, 51(1), 55-63. https:// doi.org/10.1111/area.12394

Biro, K., Pradhan, B., Buchroithner, M., \& Makeschin, F. (2011). Land use/land cover change analysis and its impact on soil properties in the northern part of Gadarif region, Sudan. Land Degradation \& Development, 24(1), 90-102. https://doi.org/10.1002/ldr.1116

Bollig, M. (2016). Adaptive cycles in the Savannah: Pastoral specialization and diversification in northern Kenya. Journal of Eastern African Studies, 10(1), 21-44. https://doi.org/10.1080/17531055.2016.1141568

Bollig, M., \& Schulte, A. (1999). Environmental change and pastoral perceptions: Degradation and indigenous knowledge in two African pastoral communities. Human Ecology, 27(3), 493-514. https://doi.org/ 10.1023/A:1018783725398

Brandt, M., Rasmussen, K., Peñuelas, J., Tian, F., Schurgers, G., Verger, A., ... Fensholt, R. (2017). Human population growth offsets climatedriven increase in woody vegetation in sub-Saharan Africa. Nature Ecology \& Evolution, 1, 0081. https://doi.org/10.1038/s41559-0170081

Breiman, L. (2001). Random forests. Machine Learning, 45(1), 5-32. https://doi.org/10.1023/A:1010933404324

Central Bureau of Statistics. (1994). Kenya population census, 1989Volume I. Retrieved from https://www.knbs.or.ke/?page_id=3142

Chalmers, N., \& Fabricius, C. (2007). Expert and generalist local knowledge about land-cover change on South Africa's wild coast. Ecology and Society, 12(1), 10. https://doi.org/10.5751/es-01977-120110

Conant, F. P. (1982). Thorns paired, sharply recurved: Cultural controls and rangeland quality in East Africa. In B. Spooner \& H. S. Mann (Eds.), Desertification and development: Dryland ecology in social perspective (pp. 111-122). London: Academic Press.

Congalton, R. G. (1991). A review of assessing the accuracy of classifications of remotely sensed data. Remote Sensing of Environment, 37(1), 35-46. https://doi.org/10.1016/0034-4257(91)90048-B

Congalton, R. G., \& Green, K. (2019). Assessing the accuracy of remotely sensed data: Principles and practices. Boca Raton: CRC Press.

Crist, E. P. (1985). A TM tasseled cap equivalent transformation for reflectance factor data. Remote Sensing of Environment, 17(3), 301-306. https://doi.org/10.1016/0034-4257(85)90102-6

de Klerk, J. N. (2004). Bush encroachment in Namibia: Report on phase 1 of the bush encroachment research, monitoring and management project [Published Government Report]. Ministry of Environment and Tourism, Government of the Republic of Namibia. Windhoek. Retrieved from https://www.namibiadigitalrepository.com/items/ show/162
Deering, D. W., \& Haas, R. H. (1980). Using Landsat digital data for estimating green biomass. Paper presented at: 30th Ann. Meeting of the Soc. for Range Management Symp. on Rangeland Remote Sensing; 17 Feb. 1977, Portland, OR; United States. Retrieved from https:// ia801203.us.archive.org/23/items/NASA_NTRS_Archive_198000243 11/NASA_NTRS_Archive_19800024311.pdf

Del Rio, T., Groot, J. C. J., DeClerck, F., \& Estrada-Carmona, N. (2018). Integrating local knowledge and remote sensing for eco-type classification map in the Barotse floodplain, Zambia. Data in Brief, 19, 22972304. https://doi.org/10.1016/j.dib.2018.07.009

Delgado-Aguilar, M. J., Hinojosa, L., \& Schmitt, C. B. (2019). Combining remote sensing techniques and participatory mapping to understand the relations between forest degradation and ecosystems services in a tropical rainforest. Applied Geography, 104, 65-74. https://doi.org/10. 1016/j.apgeog.2019.02.003

Eddy, I. M. S., Gergel, S. E., Coops, N. C., Henebry, G. M., Levine, J., Zerriffi, H., \& Shibkov, E. (2017). Integrating remote sensing and local ecological knowledge to monitor rangeland dynamics. Ecological Indicators, 82, 106-116. https://doi.org/10.1016/j.ecolind.2017.06.033

Egeru, A., Wasonga, O., Mburu, J., Yazan, E., Majaliwa, M. G. J., MacOpiyo, L., \& Bamutaze, Y. (2015). Drivers of forage availability: An integration of remote sensing and traditional ecological knowledge in Karamoja sub-region, Uganda. Pastoralism, 5, 19. https://doi.org/10. 1186/s13570-015-0037-6

Fairhead, J., \& Leach, M. (1995). False forest history, complicit social analysis: Rethinking some West African environmental narratives. World Development, 23(6), 1023-1035. https://doi.org/10.1016/0305-750X (95)00026-9

Fu, B., Stafford-Smith, M., Wang, Y., Wu, B., Yu, X., Lv, N., ... Chen, X. (2021). The global-DEP conceptual framework-Research on dryland ecosystems to promote sustainability. Current Opinion in Environmental Sustainability, 48, 17-28. https://doi.org/10.1016/j.cosust.2020. 08.009

Funk, C., Dettinger, M. D., Michaelsen, J. C., Verdin, J. P., Brown, M. E., Barlow, M., \& Hoell, A. (2008). Warming of the Indian Ocean threatens eastern and Southern African food security but could be mitigated by agricultural development. Proceedings of the National Academy of Sciences, 105(32), 11081-11086. https://doi.org/10.1073/pnas. 0708196105

Garedew, E., Sandewall, M., Söderberg, U., \& Campbell, B. M. (2009). Land-use and land-cover dynamics in the central Rift Valley of Ethiopia. Environmental Management, 44(4), 683-694. https://doi.org/10. 1007/s00267-009-9355-z

Geolnformatiks Ltd. (2017). West Pokot County Spatial Development Plan (2017-2027).

Gislason, P. O., Benediktsson, J. A., \& Sveinsson, J. R. (2006). Random forests for land cover classification. Pattern Recognition in Remote Sensing, 27(4), 294-300. https://doi.org/10.1016/j.patrec.2005.08.011

Gitelson, A. A., Kaufman, Y. J., \& Merzlyak, M. N. (1996). Use of a green channel in remote sensing of global vegetation from EOS-MODIS. Remote Sensing of Environment, 58(3), 289-298. https://doi.org/10. 1016/S0034-4257(96)00072-7

Government of the Republic of Kenya. (2012). Vision 2030 development strategy for Northern Kenya and other arid lands. Retrieved from https://www.ndma.go.ke/index.php/resource-center/policy-documents/ send/44-policy-documents/4300-vision-2030-development-strategyfor-asals

Haralick, R. M., Shanmugam, K., \& Dinstein, I. (1973). Textural features for image classification. IEEE Transactions on Systems, Man, and Cybernetics, SMC-3(6), 610-621. https://doi.org/10.1109/TSMC.1973. 4309314

Herrmann, S., Sall, I., \& Sy, O. (2014). People and pixels in the Sahel: A study linking coarse-resolution remote sensing observations to land users' perceptions of their changing environment in Senegal. Ecology and Society, 19(3), 29. https://doi.org/10.5751/ES-06710190329 
Huang, C., Wylie, B. K., Yang, L., Homer, C. G., \& Zylstra, G. (2002). Derivation of a tasselled cap transformation based on Landsat 7 at-satellite reflectance. International Journal of Remote Sensing, 23(8), 1741-1748. https://doi.org/10.1080/01431160110106113

Huete, A. R. (1988). A soil-adjusted vegetation index (SAVI). Remote Sensing of Environment, 25(3), 295-309. https://doi.org/10.1016/00344257(88)90106-X

IPPC. (2014). Summary for policymakers (climate change 2014: Impacts, adaptation, and vulnerability. Part A: gobal and sectoral aspects. Contribution of working group II to the fifth assessment report of the intergovernmental panel on climate change) (pp. 1-32). New York: Cambridge University Press. Retrieved from https://www.ipcc.ch/site/assets/ uploads/2018/02/ar5_wgll_spm_en.pdf

Jordan, C. F. (1969). Derivation of leaf-area index from quality of light on the forest floor. Ecology, 50(4), 663-666. https://doi.org/10.2307/ 1936256

Kagunyu, A. W., \& Wanjohi, J. (2014). Camel rearing replacing cattle production among the Borana community in Isiolo County of northern Kenya, as climate variability bites. Pastoralism, 4(1), 13. https://doi. org/10.1186/s13570-014-0013-6

Kamusoko, C., \& Aniya, M. (2009). Hybrid classification of Landsat data and GIS for land use/cover change analysis of the Bindura District, Zimbabwe. International Journal of Remote Sensing, 30(1), 97-115. https://doi.org/10.1080/01431160802244268

Karlson, M., Ostwald, M., Reese, H., Sanou, J., Tankoano, B., \& Mattsson, E. (2015). Mapping tree canopy cover and aboveground biomass in Sudano-Sahelian woodlands using Landsat 8 and random forest. Remote Sensing, 7(8), 10017-10041. https://doi.org/10.3390/ rs70810017

Kenya National Bureau of Statistics. (2019). 2019 Kenya population and housing census-Volume I: Population by county and sub-county. Nairobi: Kenya National Bureau of Statistics Retrieved from https://www. knbs.or.ke/?wpdmpro=2019-kenya-population-and-housing-censusvolume-i-population-by-county-and-sub-county

Kiruki, H. M., van der Zanden, E. H., Malek, Z., \& Verburg, P. H. (2017). Land cover change and woodland degradation in a charcoal producing semiarid area in Kenya. Land Degradation \& Development, 28(2), 472481. https://doi.org/10.1002/ldr.2545

Kutsch, W. L., Merbold, L., Ziegler, W., Mukelabai, M. M., Muchinda, M., Kolle, O., \& Scholes, R. J. (2011). The charcoal trap: Miombo forests and the energy needs of people. Carbon Balance and Management, 6(1), 5. https://doi.org/10.1186/1750-0680-6-5

Leutner, B., \& Horning, N. (2017). Tools for remote sensing sata analysis. Retrieved from http://bleutner.github.io/RStoolbox

Levy, K., Woster, A. P., Goldstein, R. S., \& Carlton, E. J. (2016). Untangling the impacts of climate change on waterborne diseases: A systematic review of relationships between diarrheal diseases and temperature, rainfall, flooding, and drought. Environmental Science \& Technology, 50 (10), 4905-4922. https://doi.org/10.1021/acs.est.5b06186

Liao, C., Agrawal, A., Clark, P. E., Levin, S. A., \& Rubenstein, D. I. (2020). Landscape sustainability science in the drylands: Mobility, rangelands and livelihoods. Landscape Ecology, 35, 2433-2447. https://doi.org/ 10.1007/s10980-020-01068-8

Liao, C., Clark, P. E., \& DeGloria, S. D. (2018). Bush encroachment dynamics and rangeland management implications in Southern Ethiopia. Ecology and Evolution, 8(23), 11694-11703. https://doi.org/10.1002/ ece3.4621

Lu, D., \& Batistella, M. (2005). Exploring TM image texture and its relationships with biomass estimation in Rondônia, Brazilian Amazon. Acta Amazonica, 35(2), 249-257. https://doi.org/10.1590/S004459672005000200015

Makondo, C. C., \& Thomas, D. S. G. (2018). Climate change adaptation: Linking indigenous knowledge with western science for effective adaptation. Environmental Science \& Policy, 88, 83-91. https://doi.org/ 10.1016/j.envsci.2018.06.014
Marchant, R., Richer, S., Boles, O., Capitani, C., Courtney-Mustaphi, C. J., Lane, P., ... Wright, D. (2018). Drivers and trajectories of land cover change in East Africa: Human and environmental interactions from 6000 years ago to present. Earth-Science Reviews, 178, 322-378. https://doi.org/10.1016/j.earscirev.2017.12.010

Marston, C. G., Aplin, P., Wilkinson, D. M., Field, R., \& O'Regan, H. J. (2017). Scrubbing up: Multi-scale investigation of woody encroachment in a southern African savannah. Remote Sensing, 9(5), 419. https://doi.org/10.3390/rs9050419

Maundu, P., Kibet, S., Morimoto, Y., Imbumi, M., \& Adeka, R. (2009). Impact of Prosopis juliflora on Kenya's semi-arid and arid ecosystems and local livelihoods. Biodiversity, 10(2-3), 33-50. https://doi.org/10. 1080/14888386.2009.9712842

Mialhe, F., Gunnell, Y., Ignacio, J. A. F., Delbart, N., Ogania, J. L., \& Henry, S. (2015). Monitoring land-use change by combining participatory land-use maps with standard remote sensing techniques: Showcase from a remote forest catchment on Mindanao, Philippines. International Journal of Applied Earth Observation and Geoinformation, 36, 69-82. https://doi.org/10.1016/j.jag.2014.11.007

Mistry, J., \& Berardi, A. (2016). Bridging indigenous and scientific knowledge. Science, 352(6291), 1274-1275. https://doi.org/10.1126/ science.aaf1160

Mugova, A., \& Mavunga, J. (2000). Wei integrated development project: A success story in desertification control. Desertification Control Bulletin, No. 36.

Mwampamba, T. H., Ghilardi, A., Sander, K., \& Chaix, K. J. (2013). Dispelling common misconceptions to improve attitudes and policy outlook on charcoal in developing countries. Energy for Sustainable Development, 17(2), 75-85. https://doi.org/10.1016/j.esd.2013.01.001

Mwangi, E., \& Swallow, B. (2005). Invasion of Prosopis juliflora and local livelihoods: Case study from the Lake Baringo area of Kenya. Nairobi, Kenya: World Agroforestry Centre. Retrieved from http://apps. worldagroforestry.org/downloads/Publications/PDFS/ wp03mwangi.pdf

Niang, I., Ruppel, O. C., Abdrabo, M. A., Essel, A., Lennard, C., Padgham, J., \& Urquhart, P. (2014). Africa (climate change 2014: Impacts, adaptation, and vulnerability. Part B: Regional aspects. Contribution of working group II to the fifth assessment report of the intergovernmental panel on climate change) (pp. 1199-1265). New York: Cambridge University Press Retrieved from https://www.ipcc.ch/site/ assets/uploads/2018/02/WGIIAR5-Chap22_FINAL.pdf

Nüsser, M. (2002). Pastoral utilization and land cover change: A case study from the Sanqebethu Valley, eastern Lesotho. Erdkunde, 56(2), 207221. https://doi.org/10.3112/erdkunde.2002.02.07

Nyberg, G., Knutsson, P., Ostwald, M., Öborn, I., Wredle, E., Otieno, D. J., ... Malmer, A. (2015). Enclosures in west Pokot, Kenya: Transforming land, livestock and livelihoods in drylands. Pastoralism, 5(1), 25. https://doi.org/10.1186/s13570-015-0044-7

Oduor, N. M., \& Githiomi, J. K. (2013). Fuel-wood energy properties of Prosopis juliflora and Prosopis pallida grown in Baringo District, Kenya. African Journal of Agricultural Research, 8(21), 62476-62481. https:// doi.org/10.5897/AJAR08.221

Okaka, F. O., \& Odhiambo, B. D. O. (2018). Relationship between flooding and outbreak of infectious diseases in Kenya: A review of the literature. Journal of Environmental and Public Health, 2018, 5452938. https://doi.org/10.1155/2018/5452938

Olsson, P., \& Folke, C. (2001). Local ecological knowledge and institutional dynamics for ecosystem management: A study of Lake Racken watershed, Sweden. Ecosystems, 4(2), 85-104. https://doi.org/10.1007/ s100210000061

Ordway, E. M., Asner, G. P., \& Lambin, E. F. (2017). Deforestation risk due to commodity crop expansion in sub-Saharan Africa. Environmental Research Letters, 12(4), 044015. https://doi.org/10.1088/1748-9326/aa6509

Osborne, C. P., Charles-Dominique, T., Stevens, N., Bond, W. J., Midgley, G., \& Lehmann, C. E. R. (2018). Human impacts in African 
savannas are mediated by plant functional traits. New Phytologist, 220 (1), 10-24. https://doi.org/10.1111/nph.15236

Österle, M. (2008). From cattle to goats: The transformation of east Pokot pastoralism in Kenya. Nomadic Peoples, 12(1), 81-91. https://doi.org/ 10.3167/np.2008.120105

Ouko, E., Omondi, S., Mugo, R., Wahome, A., Kasera, K., Nkurunziza, E., ... Wambua, M. (2020). Modeling invasive plant species in Kenya's northern rangelands. Frontiers in Environmental Science, 8, 69. https://doi. org/10.3389/fenvs.2020.00069

Petit, C. C., \& Lambin, E. F. (2002). Impact of data integration technique on historical land-use/land-cover change: Comparing historical maps with remote sensing data in the Belgian Ardennes. Landscape Ecology, 17(2), 117-132. https://doi.org/10.1023/A:1016599627798

Qi, J., Chehebouni, A., Huete, A. R., Kerr, Y. H., \& Sorooshian, S. (1994). Modified soil adjusted vegetation index (MSAVI) remote sensing of environment (Vol. 48). New York. NY: Elsevier.

R Development Core Team. (2008). R: A language and environment for statistical computing. Retrieved from http://www.R-project.org.

Raymond, C. M., Fazey, I., Reed, M. S., Stringer, L. C., Robinson, G. M., \& Evely, A. C. (2010). Integrating local and scientific knowledge for environmental management. Journal of Environmental Management, 91(8), 1766-1777. https://doi.org/10.1016/j.jenvman.2010.03.023

Reed, M. S., Dougill, A. J., \& Taylor, M. J. (2007). Integrating local and scientific knowledge for adaptation to land degradation: Kalahari rangeland management options. Land Degradation \& Development, 18(3), 249-268. https://doi.org/10.1002/ldr.777

Rembold, F., Oduori, S. M., Gadain, H., \& Toselli, P. (2013). Mapping charcoal driven forest degradation during the main period of Al Shabaab control in southern Somalia. Energy for Sustainable Development, 17(5), 510-514. https://doi.org/10.1016/j.esd.2013.07.001

Roden, P., \& Bergmann, C. (2015). Esther's life Story within a Dryland biography: Livelihood viability in central Pokot, Kenya. The Unfamiliar, 5(1-2), 27-32. https://doi.org/10.2218/unfamiliar.v5i1-2.1207

Roden, P., Bergmann, C., Ulrich, A., \& Nüsser, M. (2016). Tracing divergent livelihood pathways in the drylands: A perspective on two spatially proximate locations in Laikipia County, Kenya. Journal of Arid Environments, 124, 239-248. https://doi.org/10.1016/j.jaridenv. 2015.08.004

Rodriguez-Galiano, V. F., Ghimire, B., Rogan, J., Chica-Olmo, M., \& RigolSanchez, J. P. (2012). An assessment of the effectiveness of a random forest classifier for land-cover classification. ISPRS Journal of Photogrammetry and Remote Sensing, 67, 93-104. https://doi.org/10.1016/j. isprsjprs.2011.11.002

Rouse Jr, J. W., Haas, R. H., Schell, J. A., \& Deering, D. W. (1974). Monitoring vegetation systems in the Great Plains with ERTS. 1, 309-317. Retrieved from https://ntrs.nasa.gov/archive/nasa/casi.ntrs.nasa.gov/ 19740022614.pdf

Rukundo, E., Liu, S., Dong, Y., Rutebuka, E., Asamoah, E. F., Xu, J., \& Wu, X. (2018). Spatio-temporal dynamics of critical ecosystem services in response to agricultural expansion in Rwanda, East Africa. Ecological Indicators, 89, 696-705. https://doi.org/10.1016/j.ecolind.2018. 02.032

Sedano, F., Silva, J. A., Machoco, R., Meque, C. H., Sitoe, A., Ribeiro, N., ... Tucker, C. J. (2016). The impact of charcoal production on forest degradation: A case study in Tete, Mozambique. Environmental Research Letters, 11(9), 094020. https://doi.org/10.1088/1748-9326/11/9/ 094020

Serdeczny, O., Adams, S., Baarsch, F., Coumou, D., Robinson, A., Hare, W., ... Reinhardt, J. (2017). Climate change impacts in sub-Saharan Africa: From physical changes to their social repercussions. Regional Environmental Change, 17(6), 1585-1600. https://doi.org/10.1007/s10113015-0910-2

Shiferaw, H., Bewket, W., Alamirew, T., Zeleke, G., Teketay, D., Bekele, K. ... Eckert, S. (2019). Implications of land use/land cover dynamics and Prosopis invasion on ecosystem service values in Afar region, Ethiopia.
Science of the Total Environment, 675, 354-366. https://doi.org/10. 1016/j.scitotenv.2019.04.220

Shongwe, M. E., van Oldenborgh, G. J., van den Hurk, B., \& van Aalst, M. (2010). Projected changes in mean and extreme precipitation in Africa under global warming. Part II: East Africa. Journal of Climate, 24(14), 3718-3733. https://doi.org/10.1175/2010JCLI2883.1

Stevens, N., Lehmann, C. E. R., Murphy, B. P., \& Durigan, G. (2017). Savanna woody encroachment is widespread across three continents. Global Change Biology, 23(1), 235-244. https://doi.org/10.1111/gcb. 13409

Story, M., \& Congalton, R. G. (1986). Accuracy assessment: A user's perspective. Photogrammetric Engineering and Remote Sensing, 52(3), 397-399.

Sulieman, H. M., \& Ahmed, A. G. M. (2013). Monitoring changes in pastoral resources in eastern Sudan: A synthesis of remote sensing and local knowledge. Pastoralism: Research, Policy and Practice, 3, 22. https:// doi.org/10.1186/2041-7136-3-22

Taylor, R., Wanjiru, H., Johnson, O. W., \& Johnson, F. X. (2020). Modelling stakeholder agency to investigate sustainable charcoal markets in Kenya. Environmental Innovation and Societal Transitions, 35, 493-508. https://doi.org/10.1016/j.eist.2019.10.001

Thiam, A. K. (1997). Geographic information systems and remote sensing methods for assessing and monitoring land degradation in the Sahel: The case of southern Mauritania. Darks University.

Thondhlana, G., Vedeld, P., \& Shackleton, S. (2012). Natural resource use, income and dependence among san and Mier communities bordering Kgalagadi Transfrontier Park, southern Kalahari, South Africa. International Journal of Sustainable Development and World Ecology, 19(5), 460-470. https://doi.org/10.1080/13504509.2012.708908

USGS. (2017). EarthExplorer. Retrieved from https://earthexplorer. usgs.gov/

Vehrs, H.-P. (2016). Changes in landscape vegetation, forage plant composition and herding structure in the pastoralist livelihoods of east Pokot, Kenya. Journal of Eastern African Studies, 10(1), 88-110. https://doi. org/10.1080/17531055.2015.1134401

Venter, Z. S., Cramer, M. D., \& Hawkins, H.-J. (2018). Drivers of woody plant encroachment over Africa. Nature Communications, 9(1), 1-7. https://doi.org/10.1038/s41467-018-04616-8

Verschuren, D. (2004). Decadal and century-scale climate variability in tropical Africa during the past 2000 years. In R. W. Battarbee, F. Gasse, \& C. E. Stickley (Eds.), Past climate variability through Europe and Africa (pp. 139-158). Dordrecht: Springer Netherlands. https://doi. org/10.1007/978-1-4020-2121-3_8

Wasonga, V. O., Ngugi, R. K., \& Kitalyi, A. (2003). Traditional range condition and trend assessment: Lessons from Pokot and II Chamus pastoralists of Kenya. The Anthropologist, 5(2), 79-87. https://doi.org/10. 1080/09720073.2003.11890783

Xu, Y., Yu, L., Zhao, F. R., Cai, X., Zhao, J., Lu, H., \& Gong, P. (2018). Tracking annual cropland changes from 1984 to 2016 using time-series Landsat images with a change-detection and post-classification approach: Experiments from three sites in Africa. Remote Sensing of Environment, 218, 13-31. https://doi.org/10.1016/j.rse.2018.09.008

Yiran, G. A. B., Kusimi, J. M., \& Kufogbe, S. K. (2012). A synthesis of remote sensing and local knowledge approaches in land degradation assessment in the Bawku East District, Ghana. International Journal of Applied Earth Observation and Geoinformation, 14(1), 204-213. https:// doi.org/10.1016/j.jag.2011.09.016

Zaal, F., van Tienhoven, I., \& Schomaker, M. (1985). Locational development profile. Masol location. West Pokot District, Kenya. Kapenguria: Regional Development Research West Pokot/Elgeyo Marakwet.

Zaehringer, J. G., Llopis, J. C., Latthachack, P., Thein, T. T., \& Heinimann, A. (2018). A novel participatory and remote-sensing-based approach to mapping annual land use change on forest frontiers in Laos, Myanmar, and Madagascar. Journal of Land Use Science, 13(1-2), 16-31. https:// doi.org/10.1080/1747423X.2018.1447033 
Zoungrana, B., Conrad, C., Amekudzi, L., Thiel, M., Da, E., Forkuor, G., \& Löw, F. (2015). Multi-temporal Landsat images and ancillary data for land use/ cover change (LULCC) detection in the southwest of Burkina Faso, West Africa. Remote Sensing, 7(9), 12076-12102. https://doi. org/10.3390/rs70912076

\section{SUPPORTING INFORMATION}

Additional supporting information may be found online in the Supporting Information section at the end of this article.
How to cite this article: Petersen M, Bergmann C, Roden P, Nüsser M. Contextualizing land-use and land-cover change with local knowledge: A case study from Pokot Central,

Kenya. Land Degrad Dev. 2021;32:2992-3007. https://doi. org/10.1002/ldr.3961 